ВЫЯВЛЕНИЕ МЕМБРАНОСВЯЗАННЫХ ПРОТЕАЗ FRANCISELLA TULARENSIS

ФКУЗ “Иркутский научно-исследовательский противочумный институт Сибири и Дальнего Востока» Роспотребнадзора, Иркутск, Россия

Проведено исследование наличия протеолитической активности и состав протеаз в поверхностных структурах клеток шести штаммов Francisella tularensis разных подвидов. Препараты мембранной фракции возбудителя туляремии получали путем обработки микробной массы мочевиной. Субстратный электрофорез выявил три общих для всех штаммов полипептида, обладающих протеолитической активностью. У препаратов F. tularensis subsp. nearctica u F. tularensis subsp. поvicida обнаружены дополнительные полосы протеаз.

Ключевые слова: Francisella tularensis, субклеточные фракции, наружные мембраны, ферменты, протеазы протеолитическая активность

\title{
DETECTION OF MEMBRANE-BOUND PROTEASES OF FRANCISELLA TULARENSIS
}

\author{
A.V. Korneva, V.B. Nikolaev, C.N. Kozlov, E.Y. Markov, A.V. Mazepa, Y.O. Popova
}

Irkutsk Antiplague Research Institute of Siberia and Far East of Rospotrebnadzor, Irkutsk, Russia

Sterile preparations of membrane fractions were prepared by processing of live Francisella tularensis cells of different subspecies with $4.5 \mathrm{M}$ urea solution and differential centrifugation. For the first time, proteolytic activity was detected and studied by tests of radial enzyme diffusion and substrate polyacrylamide gel electrophoresis using gelatin as a substrate. Spectrum of gelatinases in the resulted preparation were detected. Quantitative inter-strain differences in the protease activities and their qualitative composition in membrane preparations of various virulent $F$. tularensis strains was analyzed. Avirulent F. tularensis 21/400 subsp. holarctica (I-214) strain demonstrated the greatest gelatinase activity in enzyme diffusion method and the lowest hydrolytic activity was seen in F. tularensis B-399 A-Cole subsp. tularensis (I-386) and F. tularensis Utah 112 subsp. novicida (I-384), other preparations showed intermediate activity. Enzyme electrophoresis in the protease spectra determined the presence of proteins with proteases activity 50-100 kDa, and in the spectrum preparations of F. tularensis I-386 and I-384 were detected additional bands of proteases.

Key words: Francisella tularensis, subcellular fractions, outer membrane, enzyme, protease, proteolytic activity

Francisella tularensis - мелкая грамотрицательная бактерия, возбудитель зоонозной инфекции туляремии, природные очаги которой широко распространены во всём Северном полушарии в пределах умеренно климатического пояса, в том числе на территории Российской Федерации. Внутри вида Francisella tularensis выделяют четыре подвида - tularensis, holarctica, mediasiatica и novicida. На территории РФ в основном циркулируют и выделяются культуры голарктического подвида возбудителя туляремии, различающиеся по чувствительности к эритромицину, что позволяет дифференцировать штаммы туляремийного микроба на два биологических варианта: биовар I Ery(s) и биовар II Ery(r).

Туляремийный микроб относится к внутриклеточным патогенам, для которых выживаемость в фагоцитах является одной из ключевых характеристик $[9,14,16]$. Несмотря на достигнутые успехи в изучении возбудителя туляремии, до настоящего времени отсутствует полная картина патогенетических механизмов и факторов, обуславливающих крайне высокую вирулентность туляремийного микроба, заражающая доза которого для человека при аэрогенном заражении составляет десять микробных клеток [1]. Существенное значение в этом процессе, вероятно, имеет способность успешно адаптироваться к широкому спектру внешних условий и типам клеток макроорганизма.

Протеолитические ферменты, присутствующие во всех живых организмах как в цитоплазме, так и в составе поверхностных структур, не только участвуют в метаболизме, но и являются факторами вирулентности высокопатогенных микроорганизмов и играют важную роль в их адаптации к условиям окружающей среды, являясь связующим звеном между её внутренней и внешней средами. Находясь на поверхности, они участвуют в инициации связывания микробных клеток с клетками хозяина, вторжении в них, адаптации и размножении внутри клеток. Часть из них, являясь специализированными гидролазами, принимают непосредственное участие в подавлении отдельных стадий иммунной защиты хозяина, обеспечивая выживание патогена в макроорганизме [2, $3,4,5,6]$.

Кроме того, данные о высоких протективных и иммуномодулирующих свойствах протеолитических ферментов $[15,17]$ открывают широкие перспективы в направлении создания специфических вакцинных препаратов на их основе, что также свидетельствует о необходимости всестороннего изучения строения и функций протеаз, входящих в состав поверхностных структур бактериальных клеток F. tularensis.

Одним из важнейших аспектов в вопросе изучения ферментов в составе мембранных структур туляремийного микроба является поиск и разработка оптимальных методов обеззараживания микробной массы и разрушения целых клеток для получения фрагментов мембран с сохранением ферментативных функций белков, находящихся в их составе и отвеча- 
ющих требованиям биологической безопасности при работе с особо опасными инфекциями.

Совершенствование средств иммунопрофилактики и диагностики непосредственно связано с исследованием клеточных структур возбудителя, ответственных за его патогенность и формирование антибактериального иммунитета. Определение различий в биологических свойствах микроба, в частности ферментов метаболизма, играющих важную роль в жизнедеятельности бактериальной клетки, может быть одним из подходов в изучении механизмов реализации патогенных свойств Francisella tularensis. Однако ранее полученные данные об участии ферментов туляремийного микроба в проявлении вирулентности и формировании иммунного ответа макроорганизма не составляют целостной картины. Поэтому вопрос идентификации факторов вирулентности, относящихся к такой функциональной группе, как ферменты метаболизма, до сих пор остаётся нерешённым. Используемые в исследованиях способы обеззараживания (кипячение, обработка формалином или фенолом) в значительной степени оказывают деструктивное воздействие на биологические свойства клеточных структур, в том числе белков микробной клетки, что делает актуальным поиск щадящих способов инактивации микробной массы, позволяющих получать специфически стерильные препараты субклеточных фракций, с сохранением биологических свойств, для их последующего изучения. В связи с этим перспективным является способ получения препаратов субклеточных фракций возбудителя туляремии путём обработки микробной массы мочевиной и её инкубирования при $37^{\circ} \mathrm{C}$ в присутствии мочевины. Установлено, что обработка раствором мочевины живых туляремийных клеток позволяет получать специфически стерильные лизаты для выделения препаратов субклеточных фракций с сохранением биологических свойств и пригодных для энзимологических исследований.

\section{ЦЕЛЬ РАБОТЫ}

Анализ полипептидного профиля и изучение протеолитической (желатиназной) активности препаратов субклеточных фракций F. tularensis разных подвидов с помощью денатурирующего электрофореза в присутствии додецилсульфата натрия в градиентном полиакриламидном геле, радиальной энзимодиффузии в агарозном геле и субстратного электрофореза в полиакриламидном геле.

\section{МАТЕРИАЛЫ И МЕТОДЫ}

Работу проводили в соответствии с санитарноэпидемиологическими правилами СП 1.3.3118-13 «Безопасность работы с микроорганизмами I-II групп патогенности (опасности)». В работе использовали шесть штаммов культур F. tularensis разных подвидов: F. tularensis В-399 A-Cole subsp. nearctica (И-386), F. tularensis A-61 subsp. mediasiatica (И-385), F. tularensis Utah 112 subsp subsp. novicida (И-384), F. tularensis 306 (117) subsp. holarctica (И-250), F. tularensis 21/400 subsp. holarctica (И-214) - авирулентный, F. tularensis 201 (15 вакцинный) subsp. holarctica (И-201) - вак- цинный штамм линии НИИЭГ, полученные из музея живых культур ФКУЗ «Иркутский научно-исследовательский противочумный институт Сибири и Дальнего Востока» Роспотребнадзора. Бактериальную массу туляремийного микроба выращивали на FT-агаре (ФБУН ГНЦ ПМБ, п. Оболенск) в течение 48 часов при температуре $37{ }^{\circ} \mathrm{C}$. Затем к суспензии микробных клеток, смытых с FT-агара стерильным 0,9\%-м раствором натрия хлорида, добавляли равный объем стерильного 9 М раствора мочевины до достижения конечной концентрации 4,5 М. После суточной экспозиции при $37^{\circ} \mathrm{C}$ ставили бактериологический контроль специфической стерильности лизата, во время которого он хранился при $4{ }^{\circ} \mathrm{C}$. Стерильный лизат микробных клеток, подвергали дифференциальному центрифугированию, освобождая от неразрушенных клеток и крупных фрагментов при 10000 g в течение 30 мин, далее полученный супернатант центрифугировали при 40000 g в течение 60 мин. Субклеточная фракция в виде осадка, представляющая собой материал поверхностных структур микробных клеток, подвергалась диализу против проточной и дистиллированной воды в течение трёх суток и лиофильно высушивалась.

Полипептидный спектр полученных фракций оценивали с помощью электрофоретического фракционирования белков в градиентном полиакриламидном геле (4-20\%) в денатурирующих условиях в присутствии 1\%-го додецилсульфата натрия (ДСН) по методу Laemmli [13]. Молекулярную массу полипептидов определяли по их электрофоретической подвижности по отношению к подвижности молекулярных маркеров, с помощью гель-документирующей системы Gel Doc XR+ и программы Image Lab 2.0.1 (Bio-Rad).

Наличие протеолитической активности в полученных препаратах проверяли с помощью радиальной энзимодиффузии в 1\%-м агарозном геле на 0,05 М Трис-HCl буферном растворе, $\mathrm{pH}=8.3$, содержащем 0,5\%-й раствор желатина и $1: 10000$ мертиолята натрия. Учёт результатов проводили после обработки геля 20\%-м раствором трихлоруксусной кислоты по образованию прозрачных зон протеолиза вокруг лунок с образцами. В качестве положительного контроля использовали раствор протеиназы К.

Спектр протеаз в образцах изучали с помощью субстратного электрофореза в 8\%-м полиакриламидном геле (ПААГ), содержащем 0,1\%-й раствор желатина, в присутствии 1\%-го ДСН по методу C. Heussen и E.B. Dowdle [10]. 0 наличии протеаз на зимограмме судили по проявлению неокрашенных полос (зон гидролиза) на фоне окрашенного субстрата, введённого при полимеризации в ПААГ, 0,25\%-м раствором Кумасси бриллиантовым синим R-250.

Статистическую обработку проводили общепринятыми методами, рассчитывая среднеарифметические величины и их ошибки.

\section{РЕЗУЛЬТАТЫ И ОБСУЖДЕНИЕ}

В результате обработки бактериальной массы раствором мочевины получены препараты субклеточных фракций, содержащие материал поверхностных структур штаммов туляремийного микроба, 
принадлежащих к разным подвидам. Электрофоретический анализ показал, наряду с существенным сходством, некоторые особенности полипептидного состава субклеточных фракций штаммов F. tularensis с разными биологическими свойствами. В количественном отношении, по данным электрофоретического фракционирования, полипептидный спектр анализируемых фракций насчитывает от 24 до 31 полипептида, молекулярные массы которых колеблются в пределах от 10 до 192 кДа (рис. 1).

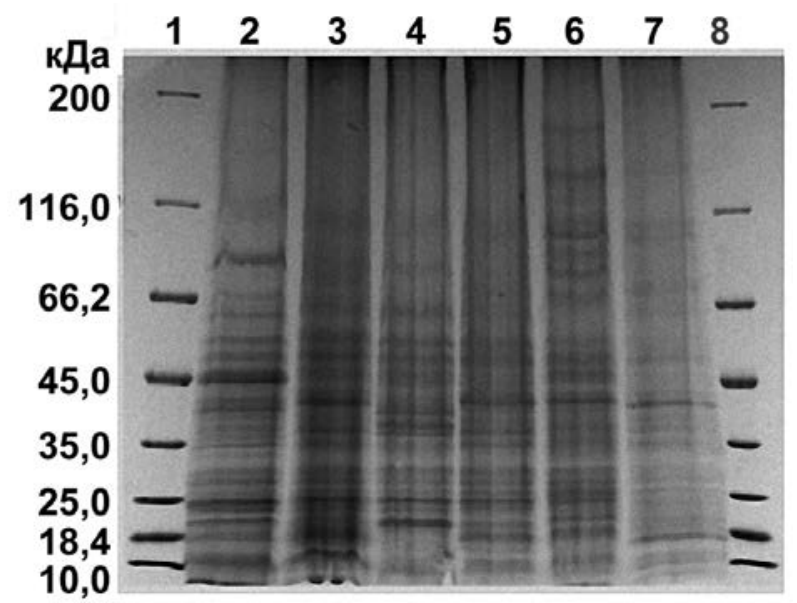

Рис. 1. Электрофоретическое фракционирование полипептидов субклеточных фракций $F$. tularensis разных подвидов в градиентном 4-20 \% ПААГ в денатурирующих условиях: 1, 8 - маркер молекулярных масс; 2 - F. tularensis subsp. holarctica И-201; 3 F. tularensis subsp. holarctica И-214; $4-F$. tularensis subsp holarctica И-250; 5 - F. tularensis subsp. novicida $И-384 ; 6-F$. tularensis subsp. mediasiatica И-385; 7 - F. tularensis subsp. nearctica $И-386$.

Протеолитическая (желатиназная) активность присутствовала в препаратах всех исследуемых штаммов независимо от подвида F. tularensis (рис. 2). Однако тест радиальной энзимодиффузии и субстратный электрофорез выявили некоторые особенности гидролиза желатина у разных штаммов. Разница в размерах и внешнем виде зон протеолиза указывает на имеющиеся различия в проявлении суммарной активности протеолитических ферментов в препаратах из разных штаммов туляремийного микроба. Наиболее интенсивной суммарной протеолитической активностью обладал препарат из авирулентного штамма F. tularensis subsp. holarctica И-214, образующий зону протеолиза размером 29,5 $\pm 3,6$ мм $(p<0,05)$. Наименьшую активность проявили препараты штаммов F. tularensis subsp. novicida И-384 и F. tularensis subsp. tularensis И-386, образовавшие зоны протеолиза $12,5 \pm 2,2$ мм и 10,5 $\pm 2,2$ мм соответственно $(p<0,05)$. Субклеточные фракции штаммов F tularensis И-385, И-201 и И-250 по активности протеаз занимают промежуточное положение с зонами протеолиза в $18,00 \pm 2,8$ мм, $13,5 \pm 2,2$ мм и $15,5 \pm 3,6$ мм соответственно $(p<0,05)$ (рис. 2).

В субстратном электрофорезе показано, что препараты субклеточных фракций туляремийного микроба обладают тремя общими для всех штаммов зонами протеолиза в пределах относительных молекулярных масс от 50 до 100 кДа. Кроме того, в препарате штамма F. tularensis subsp. nearctica И-386 присутствуют две дополнительные зоны желатиназы в низкомолекулярном диапазоне (<30 кДа) (рис. 3). Препарат штамма F. tularensis subsp. novicida И-384 обладает дополнительной зоной желатиназной активности в районе относительной молекулярной массы в 45 кДа.

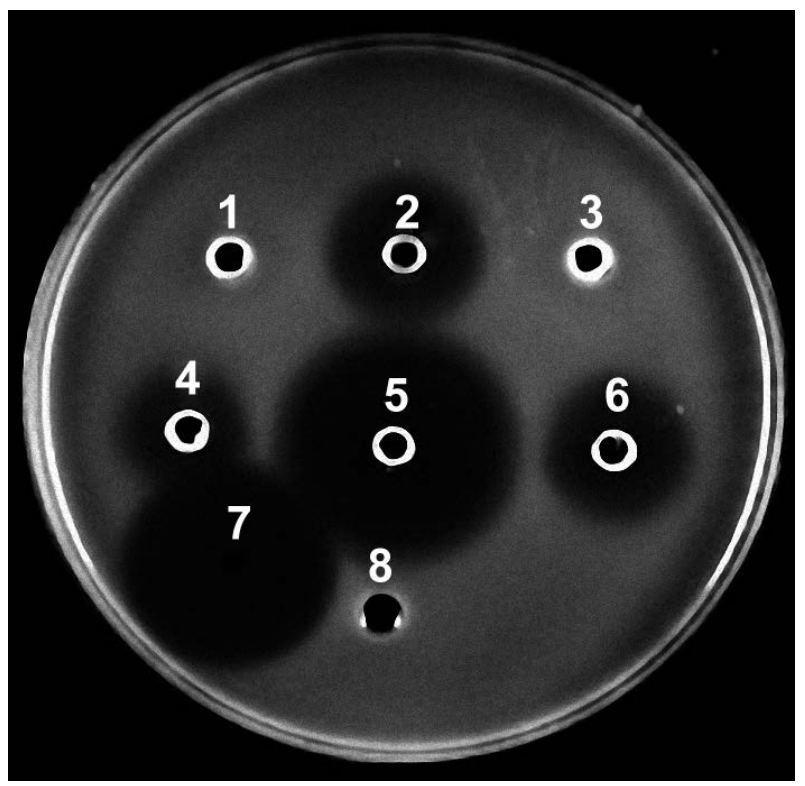

Рис. 2. Тест радиальной энзимодиффузии препаратов субклеточных фракций туляремийного микроба в $1 \%$-м агарозном геле $(0,05 \mathrm{M}$ Трис-HCl буферном растворе, $\mathrm{pH}=8.3$ ), содержащем $0,5 \%-и ̆$ раствор желатина и $1: 10000$ мертиолята натрия: 1 $F$. tularensis subsp. nearctica $И-386 ; 2-F$. tularensis subsp. mediasiatica И-385; 3 - F. tularensis subsp. novicida $И-384 ; 4-F$. tularensis subsp. holarctica И-201; 5 - F. tularensis subsp. holarctica И-214; 6 F. tularensis subsp. holarctica И-250; 7 - положительный контроль (протеиназа К); 8 - отрицательный контроль (0,9\%-й раствор хлорида натрия).

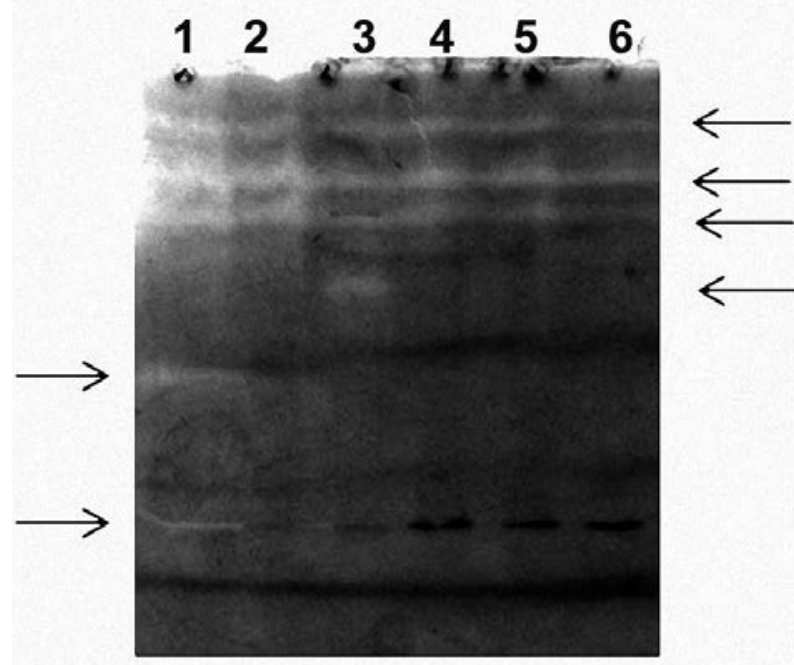

Рис. 3. Субстратный электрофорез субклеточных фракций туляремийного микроба разных подвидов в 8\%-м ПААГ, содержащий в качестве субстрата для протеаз 0,1\%-й раствор желатина. Субклеточные фракции штаммов: 1 - F. tularensis subsp. nearctica И-386; 2 F. tularensis subsp. mediasiatica И-385; $3-F$. tularensis subsp. novicida $И-384 ; 4$ - $F$. tularensis subsp. holarctica $И-250 ; 5$ - F. tularensis subsp. holarctica И-214; 6 - F. tularensis subsp. holarctica $И-201$. 
Таким образом, образцы штаммов F. tularensis subsp. nearctica И-386 и F. tularensis subsp. novicida И-384, обладая довольно низкой суммарной желатиназной активностью, в сравнении с другими штаммами, тем не менее, имеют более широкий спектр протеаз, судя по относительной молекулярной массе.

Изучение мембранных белков, как активных компонентов поверхностных структур клетки, представляет собой определённые сложности, связанные прежде всего с интеграцией белков в липидный бислой наружной мембраны, которая обуславливает их функциональные и биохимические свойства. Эта особенность заставляет современных исследователей использовать различные методы выделения и очистки мембранных белков с применением биотинилирования [7], детергентов [8], карбоната натрия [12], а также осмотического лизиса клеток [11]. В представленной работе был использован оригинальный метод обработки клеток туляремийного микроба 4,5 М мочевиной, обладающей лизирующим и стерилизующим свойствами, а также способной обратимо ингибировать активность ферментов. Таким образом, удалось получить специфически стерильные препараты субклеточных фракций F. tularensis без потери биохимической активности, что позволяет использовать их в дальнейшем для изучения ферментов поверхностных структур возбудителя туляремии с применением методов протеомного анализа.

Важным аспектом, обнаруженным с помощью методов радиальной энзимодиффузии и субстратного электрофореза в ПААГ, является несоответствие качественных и количественных характеристик желатиназной активности в препаратах штаммов разных подвидов. Наибольшей суммарной протеолитической активностью отличались авирулентные (F. tularensis subsp. holarctica И-214) или слабовирулентные (F. tularensis subsp. mediasiatica И-385, F. tularensis subsp. holarctica, F. tularensis subsp. holarctica) штаммы, в то время как штаммы с высокой вирулентностью (F. tularensis subsp. nearctica И-386 и F. tularensis subsp. novicida И-384), проявляя меньшую протеазную активность, обладают более широким спектром протеаз по относительной молекулярной массе. Возможно, такая особенность является следствием адаптации и специализации ферментативного аппарата поверхностных структур F. tularensis разных подвидов в связи с их биологическими особенностями (в том числе вирулентностью), что, несомненно, требует дальнейшего исследования, так как идентификация протеаз поверхностных структур туляремийного микроба расширяет наши представления о ферментативной активности и её локализации в субклеточных структурах возбудителя туляремии, а также способствует выяснению роли гидролаз в обеспечении его высокого патогенного потенциала как облигатного внутриклеточного паразита.

\section{ЛИТЕРАТУРА \\ REFERENCES}

1. Олсуфьев Н.Г. Таксономия, микробиология и лабораторная диагностика возбудителя туляремии. М.: Медицина, 1975. - 192 с.
Olsufyev NG (1975). Taxonomy, microbiology and laboratory diagnosis of tularemia pathogen [Taksonomiya, mikrobiologiya i laboratornaya diagnostika vozbuditelya tulyaremii], 192.

2. Павлович Н.В., Шиманюк Н.И., Мишанькин Б.Н. Нейраминидазная активность представителей рода Francisella // Журн. микробиол. - 1992. - № 9-10. C. 8-10.

Pavlovich NV, Shimanyuk NI, Mishankin BN (1992). Neuraminidase activity of Francisella genus [Neyraminidaznaya aktivnost' predstaviteley roda Francisella]. Zhurnal mikrobiologii, (9-10), 8-10.

3. Родионова И.В. Дифференциация географических рас Francisella tularensis на основании активности цитруллинуреидазы // Лабор. дело. - 1970. - № 1. C. $42-43$.

Rodionova IV (1970). Differentiation of Francisella tularensis geographical races based on the citrulline ureidase activity [Differentsiatsiya geograficheskikh ras Francisella tularensis na osnovanii aktivnosti tsitrullinureidazy]. Laboratornoe delo, (1), 42-43.

4. Шеенков Н.В., Опочинский Э.Ф., Валышев А.В. и др. Факторы персистенции Francisella tularensis // Журн. микробиол., эпидемиол. и иммунобиол. 2006. - № 1. - C. 63-68.

Sheenkov NV, Opochinskiy EF, Valyshev AV et al. (2006). Persistence factors of Francisella tularensis [Faktory persistentsii Francisella tularensis]. Zhurnal mikrobiologii, epidemiologii i immunobiologii, (1), 63-68.

5. Шиманюк Н.Я., Павлович Н.В., Мишанькин Б.Н. Супероксиддисмутазная активность у представителей рода Francisella // Журн. микробиологии, эпидемиологии и иммунобиологии. - 1992. - № 5-6. - С. 7-9.

Shimanyuk NY, Pavlovich NV, Mishankin BN (1992). Superoxide dismutase activity in Francisella genus [Superoksiddismutaznaya aktivnost' u predstaviteley roda Francisella]. Zhurnal mikrobiologii, epidemiologii i immunobiologii, (5-6), 7-9.

6. Bina XR, Wang C, Miller MA et al. (2006). The Bla2 $\beta$-lactamase from the live-vaccine strain of Francisella tularensis encodes a functional protein that is only active against penicillin-class $\beta$-lactam antibiotics. Arch. Microbiol., 186 (3), 219-228.

7. Chandler JC, Sutherland MD, Harton MR, Molins CR, Anderson RV, Heaslip DG et al. (2015). Francisella tularensis LVS surface and membrane proteins as targets of effective post-exposure immunization for tularemia. J. Proteome Res., (14), 664-675.

8. Dresler J, Klimentova J, Stulik J (2014). Francisella tularensis membrane complexome by bluenative/SDSPAGE. J. Proteomics, (75), 257-269.

9. Fortier AH, Green SJ, Polsinelli TR, Jones T, Crawford RM, Leiby DA, Elkins KL, Meltzer MS, Nacy CA (1994). Life and death of an intracellular pathogen: Francisella tularensis and the macrophage. Immunol. Ser., (60), 349-361.

10. Heussen C, Dowdle EB (1980) Electrophoretic analysis of plasminogen activators in polyacrylamide gels containing sodium dodecyl sulfate and copolymerized substrates. Anal. Biochem., 102 (1), 196-202

11. Huntley JF, Conley PG, Hagman KE, Norgard MV (2007). Characterization of Francisella tularensis outer membrane proteins. J. Bacteriol., (189), 561-574. 
12. Janovská S, Pávková I, Hubálek M, Lenco J, Macela A, Stulík J (2007). Identification of immunoreactive antigens in membrane proteins enriched fraction from Francisella tularensis LVS. Immunol. Lett., (108), 151-159.

13. Laemmli UK, Favre M (1973). Maturation of the head of bacteriophage T4. I. DNA packaging events. J. Mol. Biol., 80 (4), 575-599.

14. Mohapatra NP, Shilpa S, Rajaram MVS, Dang MC, Reilly TJ, El Benna J, Schlesinger LS, Gunn JS (2010). Francisella acid phosphatases inactivate NADPH oxidase complex components in human phagocytes by dephosphorylation. J. Immun., 184 (9), 5141-5150.

15. Nelson DC, Garbe J, Collin M (2011). Cysteine proteinase SpeB from Streptococcus pyogenes - a potent modifier of immunologically important host and bacterial proteins. Biochem., 392 (12), 1077-1088

16. Oyston PCF (2008). Francisella tularensis: unravelling the secrets of an intracellular pathogen. J. Med. Microbiol., 57 (8), 921-930.

17. Potempa J, Pike R (2009). Corruption of innate immunity by bacterial proteases. J. Innate Immun., 1 (2), 70-87.

\section{Сведения об авторах Information about the authors}

Корнева Александра Владимировна - младший научный сотрудник ФКУЗ «Иркутский научно-исследовательский противочумный институт Сибири и Дальнего Востока» Роспотребнадзора (664047, г. Иркутск, ул. Трилиссера, 78; тел.: 8 (3952) 22-01-35; e-mail: adm@chumin.irkutsk.ru)

Korneva Alexandra Vladimirovna - Junior Research Officer of Irkutsk Antiplague Research Institute of Siberia and Far East of Rospotrebnadzor (664007, Irkutsk, Trilisser str., 78; tel.: +7 (3952) 22-01-35; e-mail: adm@chumin.irkutsk.ru)

Николаев Валерий Борисович - кандидат медицинских наук, старший научный сотрудник ФКУЗ «Иркутский научноисследовательский противочумный институт Сибири и Дальнего Востока»

Nikolaev Valeriy Borisovich - Candidate of Medical Sciences, Senior Research Officer of Irkutsk Antiplague Research Institute of Siberia and Far East of Rospotrebnadzor

Козлов Станислав Николаевич - научный сотрудник ФКУЗ «Иркутский научно-исследовательский противочумный институт Сибири и Дальнего Востока»

Kozlov Stanislav Nikolayevich - Research Officer of Irkutsk Antiplague Research Institute of Siberia and Far East of Rospotrebnadzor

Марков Евгений Юрьевич - доктор биологических наук, старший научный сотрудник, заведующий биохимическим отделом ФКУЗ «Иркутский научно-исследовательский противочумный институт Сибири и Дальнего Востока»

Markov Evgeniy Yuryevich - Doctor of Biological Sciences, Senior Researcher, Head of the Biochemical Department of Irkutsk Antiplague Research Institute of Siberia and Far East of Rospotrebnadzor

Мазепа Андрей Владимирович - кандидат медицинских наук, старший научный сотрудник ФКУЗ «Иркутский научноисследовательский противочумный институт Сибири и Дальнего Востока»

Mazepa Andrey Vladimirovich - Candidate of Medical Sciences, Senior Research Officer of Irkutsk Antiplague Research Institute of Siberia and Far East of Rospotrebnadzor

Попова Юлия Олеговна - лаборант ФКУЗ «Иркутский научно-исследовательский противочумный институт Сибири и Дальнего Востока»

Popova Yuliya Olegovna - Laboratory Assistant of Irkutsk Antiplague Research Institute of Siberia and Far East of Rospotrebnadzor 